\title{
Standards needed for foot-and-mouth tests
}

\section{Sally Goodman, Paris}

Simple tests for foot-and-mouth disease that differentiate between vaccinated, infected and 'carrier' livestock could become available quickly if international agreement was reached on sensitivity and specificity, a meeting in Paris was told last week.

The International Scientific Conference on Foot-and-Mouth Disease brought together representatives of the UN Food and Agriculture Organization (FAO) and the main intergovernmental animal-health organization, the Office International des Epizooties (OIE), which covers 157 countries.

Delegates heard that such tests would be highly valuable to countries that want to maintain disease-free status and export livestock or meat after a vaccination programme or epidemic. The tests would make it far easier for countries to vaccinate animals, rather than slaughter them, as Britain has done, in response to outbreaks of the disease.

The diagnostic tests in question are based on enzyme-linked immunosorbent assay techniques. These can differentiate between

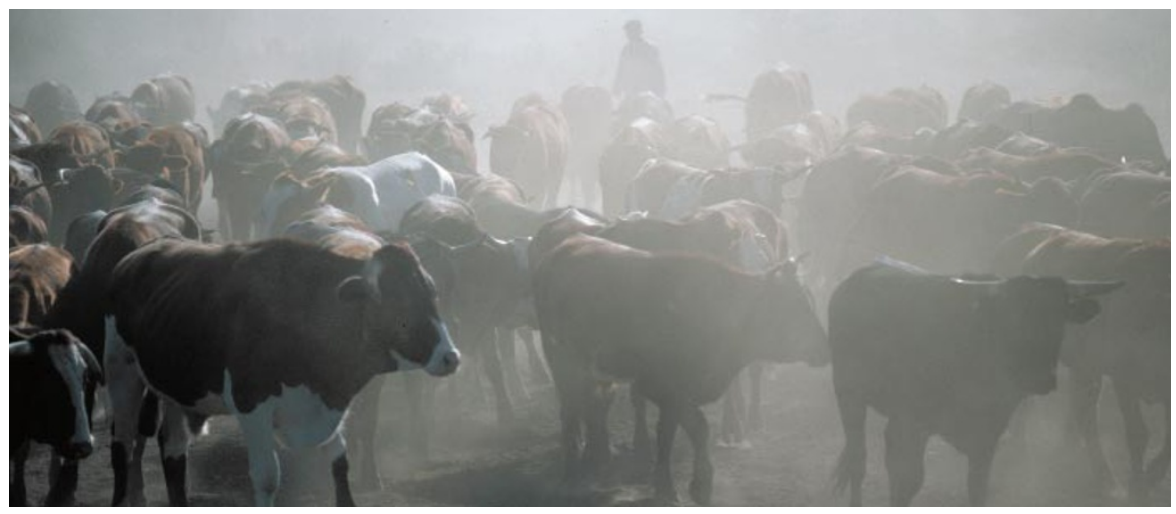

Under examination: vaccination against foot-and-mouth disease could become more common.

antibodies in the blood against structural proteins found in whole viruses and against nonstructural proteins, which are produced as the virus replicates. Because the vaccines tend to be produced from inactivated viral particles, vaccinated animals do not usually generate antibodies against the non-structural proteins and so can be identified by the assays.

"The tests are proving useful but they

\section{Reef gets off the starting blocks}

David Adam, London

Marine scientists in Scotland are poised to dump one and a quarter million concrete blocks onto the seabed to study the effects that artificial reefs have on sea-life.

Weighing over 40,000 tonnes and taking more than two years to build, the reef will help researchers to study how marine animals select and colonize habitats, as well as offering clues to how such giant constructions affect local sea currents and seabed sediment quality.

The project, which will cost $\mathfrak{E} 1.5$ million (US\$2 million), has now been granted a licence by the Scottish parliament. The first blocks will be dropped next month.

The reef is being built off the island of Lismore in Loch Linnhe, near Oban on the west coast of Scotland. Martin Sayer, a marine scientist with the Scottish Association for Marine Science (SAMS) laboratory at Dunstaffnage in Argyll, who is directing the scheme, says that most scientific research on artificial reefs has taken place on industrial installations such as breakwaters. "This will be different because its primary objective is experimental," he explains.

The reef will provide a platform for various SAMS experiments, he says, but will also be available to other research groups. A marine mammal team at the University of St Andrews has already arranged to use it to study porpoises.

The concrete blocks will be dumped in 24 separate reefs over an area the size of six football pitches. To test the effects of different reef and block shapes, half of the blocks will be solid, half will have holes, and both kinds will be used in square- and pentagon-shaped reef designs.

http://www.sams.ac.uk/sams/dml/projects/reef

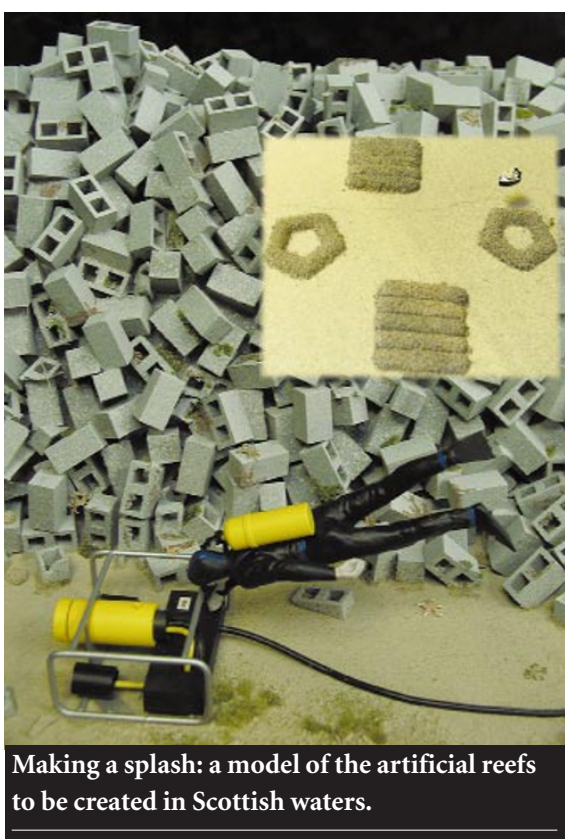

aren't yet $100 \%$ perfect," said Tony Garland, of Britain's Institute for Animal Health (IAH) in Pirbright, Surrey. "They are currently only suitable for diagnosis at herd level, not at the individual level." The IAH and the Istituto Zooprofilattico Sperimentale in Brescia, Italy, in collaboration with the Dutch vaccine company Intervet, hope to have their test on the market in September. Another commercial test has been produced by United Biomedical, a pharmaceutical company based in New York state.

But before they can be produced in sufficient quantities for mass screening or be accepted by the World Trade Organization as proof of disease-free status for export purposes, the tests need to be harmonized against a set of standard varieties of the disease virus. The complexity of the foot-andmouth virus and its wide range of hosts makes this standardization hard to achieve.

The process could take between one and three years, according to Bernard Vallat, director-general of the OIE. Another problem is that the OIE's general assembly, which has the final vote on such standardization, meets only once a year.

At last week's conference, experts called for international concerted action to speed up the process. They proposed a list of recommended actions on foot-and-mouth disease to be put before the OIE's annual meeting in May.

"Steps should be taken on preventative measures in areas where the virus is endemic," said John Crowther, a member of a Vienna-based collaboration between the International Atomic Energy Agency and the FAO animal-health division.

The meeting also recommended special provision for emergency vaccination of endangered species and those carrying rare genetic material, without prejudice to the disease status of the host country, provided that the animals are physically separated from other populations. But little research has been done on the effectiveness of vaccines in rare and exotic species.

http://www.oie.int 